Kumawula, Vol. 3, No.3, Desember 2020, Hal 539 - 547 DOI: https://doi.org/10.24198/kumawula.v3i3.31078

ISSN 2620-844X (online)

Tersedia online di http://jurnal.unpad.ac.id/kumawula/index

\title{
PENGEMBANGAN POTENSI KEWIRAUSAHAAN DENGAN PRINSIP PENTA HELIX DI DESA MARGAMEKAR KABUPATEN SUMEDANG
}

\author{
Ari Ganjar Herdiansah \\ Departemen Ilmu Politik, Universitas Padjadjaran \\ Korespondensi: ari.ganjar@unpad.ac.id
}

\begin{abstract}
ABSTRAK
Pengembangan potensi kewirausahaan di desa merupakan sarana dalam meningkatkan kesejahteraan warga desa. Kegiatan Pengabdian Kepada Masyarakat (PPM) ini bertujuan mengelola potensi kewirausahaan desa dengan metode membangun kerjasama lintas lima pemangku kepentingan (penta helix) di Desa Margamekar Kabupaten Sumedang. Dengan berkolaborasi dengan mahasiswa Kuliah Kerja Nyata (KKN) Universitas Padjadjaran Tahun Akademik 2020, kegiatan ini berupaya meningkatkan kemampuan warga dalam mengelola usahanya dengan memanfaatkan berbagai institusi di sekitar desa dan membangun jejaring dengan pihak-pihak yang dapat membantu mengembangkan wirausaha desa. Berbagai pemangku kepentingan yang dilibatkan pada kegiatan ini antara lain Universitas Padjadjaran, Bank Jawa Barat dan Banten, peliput media, komunitas penggerak Usaha Mikro, Kecil, Menengah (UMKM), dan Pemerintah Desa Margamekar. Efektifvitas dari kegiatan ini kemudian diukur dengan menggunakan survei pra-test dan post-test terhadap para warga yang berpartisipasi. Olahan survei menunjukkan hasil yang positif, artinya para peserta terbukti menerima manfaat dari kegiatan ini mulai dari aspek pengetahuan memetakan potensi usaha, menetapkan strategi marketing, dan teknik pengelolaan usaha. Akhir dari kegiatan ini juga menyarankan supaya upaya pengembangan potensi kewirausahaan desa perlu dilakukan secara sistematis dan berkelanjutan.
\end{abstract}

Kata kunci: Kewirausahaan; Pengabdian pada Masyarakat; Penta helix; Desa.

\begin{abstract}
The development of entrepreneurial potential in the village is a means to improve the welfare of villagers. The Community Service Activities (PPM) aims to manage the potential of village entrepreneurship by the method of building cross-stakeholder cooperation (penta helix) in Margamekar Village, Sumedang Regency. By collaborating with Padjadjaran University's Academic Year Real Work Lecture (KKN) 2020, this activity seeks to improve the ability of citizens to manage their businesses by utilizing various institutions around the village and building networks with parties who can help develop village entrepreneurs. Various stakeholders involved in this activity include Padjadjaran University, Bank of West Java and Banten, CNN Indonesia, the community of Micro, Small, Medium Enterprises (UMKM), and the Village Government of Margamekar. The effectiveness of this activity is then measured using a pretest and post-test survey of the participating citizens. Processed surveys show positive results, meaning that participants are proven to receive benefits from this activity starting from the aspect of knowledge mapping business potentials, establishing marketing strategies, and business management techniques. The end of this activity also suggested that efforts to develop village entrepreneurship potential need to be carried out in a more sophisticated way and continuously.
\end{abstract}

Keywords: Entrepreneurship; Community Service; Penta helix; Village.

\section{PENDAHULUAN}

Desa memiliki beragam potensi perekonomian yang dapat menopang pembangunan nasional. Namun, di saat yang sama desa merupakan penyumbang kemiskinan paling besar. Berdasarkan data BPS pada 2018, kemiskinan di desa mencapai angka 13,1 persen, sedangkan di perkotaan sebesar 6,89 persen (Handayani, 2020). Sementara itu, potensi perekonomian di desa belum banyak digali dan dikelola. Karena itu, perguruan tinggi turut berkontribusi dalam rangka meningkatkan produktivitas kegiatan ekonomi desa salah 
satunya melalui program Pengabdian pada Masyarakat (PPM). Kegiatan PPM Unviersitas Padjadjaran merupakan salah satu implementasi Tri Dharma Perguruan Tinggi sebagai sarana bagi civitas akademika kampus, terutama dosen dan mahasiswa dalam mengatasi berbagai permasalahan yang ada di masyarakat. Pada 2020, Universitas Padjadjaran menyelenggarakan kegiatan PPM yang terintegrasi dengan Kuliah Kerja Nyata (KKN) Mahasiswa dengan tema mengembangkan potensi kewirausahaan desa. Dengan menggunakan berbagai sumber daya, kegiatan ini diharapkan dapat memaksimalkan berbagai potensi kewirausahaan masyarakat desa baik yang sudah maupun memiliki potensi usaha agar bisa lebih beradaptasi dengan perkembangan teknologi agar usaha masyarakat desa semakin maju sekaligus mahasiswa diharapkan dapat menjadi katalisator dalam peningkatan kesejahteraan warga di pedesaan (Karlina, Halim, Azizi, Athusholihah, \& Tarliyah, 2019). Program ini dilaksanakan dengan menyesuaikan kegiatan riset serta pengabdian kepada masyarakat yang dilakukan oleh dosen dan mahasiswa lintas keilmuan dengan senantiasa membawa nilai-nilai kebersamaan Unpad. Melalui PPM tematik kewirausahaan yang dilakukan di pedesaan, dosen dan mahasiswa pun memperoleh penerapan dari aspek aksiologi ilmu pengetahuan yang dikembangkannya selama ini di perguruan tinggi (Direktorat Riset Pengabdian Kepada Masyarakat dan Inovasi Universitas Padjadjaran, 2019).

Kegiatan PPM dan KKN mahasiswa tematik kewirausahaan dilaksanakan di Desa Margamekar, Kecamatan Sumedang Selatan, Kabupaten Sumedang, Jawa Barat. Sasarannya adalah UMKM dan potensi pariwisata desa. Desa Margamekar terletak di bagian selatan Kabupaten Sumedang. Lokasi Desa Margamekar terbilang dekat dengan ibukota Kabupaten Sumedang, yakni hanya $2 \mathrm{Km}$. Sementara itu, jarak ke ibukota provinsi Jawa Barat yakni Kota Bandung, adalah sejauh 45 $\mathrm{Km}$. Kondisi geografis dicirikan oleh kontur perbukitan dengan variasi ketinggian antara $200 \mathrm{~m}^{2}$ hingga $900 \mathrm{~m}^{2}$. Desa ini memiliki luas wilayah sekitar $1.385 \mathrm{Km}^{2}$. Sebagian lahannya digunakan untuk area persawahan dan ladang yaitu 188 Ha untuk sawah dan 130,45 Ha untuk ladang atau huma. Di desa ini juga terdapat hutan rakyat seluas 150 Ha dan hutan negara seluas 228 Ha. Adapun jumlah penduduk Desa Margamekar adalah 4.619 jiwa pada tahun 2019. Pertumbuhan penduduk desa ini cenderung stagnan atau minus, di mana pada awal tahun terdapat 4.623 jiwa. Berkurangnya jumlah penduduk antara lain karena perpindahan dan kematian. Mata pencaharian warga Desa Margamekar umumnya mengikuti pola penggunaan lahan, yakni petani (200 orang), buruh tani (263 orang), dan buruh/karyawan (442 orang), wiraswasta (472 orang), PNS dan TNI (105 orang), dan sebagian kecil bergerak di sektor perdagangan (42 orang). Berdasarkan latar belakang pendidikan, penduduk lulusan setingkat sekolah dasar adalah yang paling banyak, yakni 1621 orang, setingkat sekolah menengah pertama sebanyak 784 orang, dan setingkat sekolah menengah pertama sejumlah 862 orang. Adapun warga yang mengenyam pendidikan tinggi hanya sekitar 32 orang (Pemerintah Desa Margamekar, 2019).

Berdasarkan tingkat kesejahteraannya, masih ada penduduk Desa Margamekar yang kurang sejahtera. Penduduk yang tergolong di ambang batas kemiskinan antara lain pada taraf keluarga sejahtera I sejumlah 123 orang, keluarga sejahtera II 216 orang, dan keluarga sejahtera III sebanyak 1001 orang. Selain itu, terdapat golongan pra sejahtera atau fakir terdapat 1 orang. (Pemerintah Desa Margamekar, 2019). Mempertimbangkan kondisi sosial ekonomi penduduk yang masih rendah, potensi kewirausahaan diharapkan dapat meningkatkan taraf kesejahteraan warga Desa Margamekar. Program PPM dan KKN mahasiswa Unpad bekerjasama dengan Badan Usaha Milik Desa (BUMDes) Margamekar untuk menggali potensi dan mengembangkan potensi kewirausahaan desa. Pelibatannya BUMDes adalah upaya strategis dalam membangun kemandirian pemerintah desa di bidang kegiatan ekonomi produktif masyarakat (Widianingsih, Setiawan, \& Chuddin, 2020). 
Untuk mengoptimalkan capaian (outcome) dari kegiatan PPM, program ini menggunakan prinsip penta helix dengan melibatkan pihakpihak pemangku kepentingan antara lain perguruan tinggi (Universitas Padjadjaran), swasta (perbankan, dalam hal ini Bank Jawa Barat dan Banten), komunitas (kelompok UMKM Desa Margamekar), pemerintah (Pemerintah Desa Margamekar), dan media (dalam hal ini wartawan dari CNN Indonesia).

Penta helix merupakan prinsip kerjasama kemitraan yang dibangun oleh berbagai pihak pemangku kepentingan dengan latar belakang yang berbeda. Sinergi kemitraan ini dibentuk agar tujuan dapat dicapai secara efektif, efisien, dan berkelanjutan dengan membawa nilai-nilai kebersamaan berdasarkan orientasi kemaslahatan bagi masyarakat, negara, dan dunia (Awaluddin, 2015). Prinsip penta helix digunakan dalam kegiatan ini dengan tujuan dapat mendorong potensi kewirausahaan desa di Desa Margamekar yang bersumber dari daya masyarakat desa itu sendiri. Landasan filosofi dari metdode penta helix terletak pada visinya yang menempatkan kemaslahatan baik di tingkat lokal, nasional, dan global sebagai keutamaan dalam setiap tujuan organisasi. Terutama bagi perguruan tinggi, luaran (outcome) dari setiap kewajiban baik itu pembelajaran, penelitian, dan pengabdian seyogyanya memberikan manfaat secara universal. Konsep kemitraan strategis penta helix inilah yang diterapkan sebagai pendekatan dalam PPM ini dengan harapan warga Desa Margamekar dapat mengembangkan potensi desanya secara berdikari.

Pelaksanaan kegiatan PPM ini didukung oleh KKN mahasiswa Unpad yang terdiri atas 19 (sembilan belas) orang mahasiswa dari berbagai fakultas, yakni tiga mahasiswa Fakultas Ekonomi dan Bisnis, satu mahasiswa Fakultas Kedokteran, satu mahasiswa Fakultas Matematika dan Ilmu Pengetahuan Alam, tiga mahasiswa Fakultas Pertanian, satu mahasiswa Fakultas Ilmu Sosial dan Ilmu Politik, dua mahasiswa Fakultas Psikologi, empat mahasiswa Fakultas Ilmu Komunikasi, tiga mahasiswa Fakultas
Perikanan dan Ilmu Kelautan, dan satu mahasiswa Fakultas Farmasi. Tujuan melibatkan mahasiswa KKN ini adalah agar mahasiswa dapat berkolaborasi dengan dosen dalam melaksanakan pengabdian dan membantu masyarakat dalam mengembangkan UMKM dengan pendekatan prinsip penta helix. Para mahasiswa yang terlibat diharapkan memiliki kemampuan sebagai agen katalisator peningkatan kewirausahaan di masyarakat yang lebih luas.

\section{METODE}

Program-program yang dilaksanakan pada kegiatan PPM dan KKN ini antara lain survei pendahuluan serta pendataan UMKM dan potensi pariwisata. Selanjutnya, tim mengidentifikasi sumber permodalan, permasalahan pelaku UMKM dan pengelola daerah pariwisata, pembuatan program untuk menanggulangi permasalahan yang dihadapi pelaku UMKM, dan pengelolaan daerah pariwisata. Pada tahap penerapan program, tim melakukan sosialisasi program kepada pelaku UMKM dan pengelola daerah pariwisata, penanggulan permasalahan yang dihadapi pelaku UMKM, dan pengelolaan daerah pariwisata. Prinsip penta helix yang diterapkan pada kegiatan PPM ini adalah serangkaian kegiatan pada dimulai dari pemetaan sosial, pendampingan (analisis kebutuhan dan masalah, pendekatan terhadap pihak-pihak pemangku kepentingan, sosialisasi terhadap warga), hingga pelaksanaan bengkel kerja. Sebelum pelaksanaan PPM dan KKN, perwakilan mahasiswa menerima pembekalan terlebih dahulu mengenai arahan pelaksanaan KKN kewirausahaan yang dilaksanakan selama satu hari pada agar mahasiswa dapat mengerti maksud dan tujuan dengan pendekatan karakter dan mampu menerapkan business model canvas serta analisis strength, weakness, opportunity, threat (SWOT) pada pelaku usaha. Tim KKN kemudian melaksanakan rapat perencanaan dengan dosen PPM untuk mempersiapkan program kerja sebagai strategi mencapai tujuan secara efektif. 
Dalam mendapatkan gambaran spesifik tentang kondisi sosial ekonomi di Desa Margamekar, tim PPM-KKN menggunakan teknik pemetaan sosial. Teknik ini tidak hanya ditujukan untuk mengumpulkan informasi meliputi berbagai potensi yang dapat menunjang pengembangan kewirausahaan desa, tetapi juga menentukan area kesepakatan (area of agreement) di mana komunitaskomunitas warga dapat berpartisipasi (Vavilina \& Skalaban, 2015). Teknik pemetaan sosial dilakukan dengan cara observasi terkait kondisi masyarakat, seperti jenis-jenis UMKM dan karakteristik masyarakat, serta potensi objekobjek pariwisata. Hasil observasi kemudian didiskusikan lebih lanjut untuk merumuskan UMKM yang akan dikembangkan. Perumusan potensi dilakukan dengan menggunakan business model canvas dan analisis SWOT. Data yang telah diperoleh kemudian didiskusikan oleh dosen dan mahasiswa dalam rangka mengidentifikasi permasalahan dan solusi untuk meningkatkan potensi UMKM dan pariwisata.

Program aksi tim PPM dan KKN dilakukan melalaui kegiatan pelatihan teknis yang dilaksanakan dalam bentuk bengkel kerja dengan tema kewirausahaan, copywriting konten media sosial, dan peminjaman modal kepada bank. Selain kegiatan bengkel kerja, tim KKN membantu warga pelaku usaha membangun website, booklet dan Instagram sebagai media pemasaran online yang dikelola secara berkelanjutan melalui pemerintah desa. Tim juga menata hubungan kemitraan dengan komunitas UMKM dengan bank supaya masyarakat mampu mengakses pinjaman modal dari bank.

Kegiatan PPM ditutup dengan acara lokakarya dengan tema "Prinsip Penta Helix dalam Pengembangan UMKM”. Kegiatan tersebut menghadirkan para pemangku kepentingan yang dapat meningkatkan potensi kewirausahaan secara berdikari di Desa Margamekar. Mereka antara lain berasal dari (a) unsur perguruan tinggi (Universitas Padjadjaran) yang memberikan materi tentang prinsip penta helix dan bagaimana menjalankan prinsip tersebut dalam rangka mengelola potensi kewirausahaan desa, (b) unsur dari swasta (Bank Jabar Banten) yang memberikan sosialisasi tentang tata cara peminjaman modal khusus UMKM, (c) dari unsur pemerintahan (Pemerintah Desa Margamekar) yang menerangkan tentang upaya pemerintah desa dan Badan Usaha Milik Desa (BUMDes) dalam mendukung potensi kewirausahaan di Margamekar, (d) komunitas UMKM Desa Margamekar yang dengan bantuan mahasiswa KKN mengadakan seminar tentang entrepreneurship dan copywriting di internet, dan (e) dari unsur media (wartawan CNN Indonesia) yang memberikan materi tentang cara-cara supaya produk UMKM dapat diliput oleh media massa demi meningkatkan penjualan. Para peserta lokakarya terdiri dari perwakilan tiap RT/RW, kelompok kerja, UMKM, PKK, Kader dan Warga Desa Margamekar. Untuk memastikan efektivitas kegiatan, tim melakukan pra-test dan post-test kepada para peserta lokakarya.

\section{HASIL DAN PEMBAHASAN}

\section{Bengkel Copywriting dan Entrepreneurship}

Potensi kewirausahaan di Desa Margamekar digali dan ditingkatkan melalui pengembangan UMKM desa. Berdasarkan hasil identifikasi permasalahan, berbagai potensi kewirausahan desa dapat ditelusuri dari UMKM. Mereka merupakan unit-unit yang memiliki peran penting dalam meningkatkan perekonomian skala rumah tangga. Meskipun relatif kecil cakupan usahanya, UMKM berpotensi menyerap tenaga kerja di desa dan membantu perekonomian keluarga terutama melalui peran perempuan (ibu rumah tangga) serta menekan angka pengangguran di desa (Sugiarti, Sari, \& Hadiyat, 2020). Namun, sebagian besar dari mereka belum memiliki pengetahuan dan keterampilan mengelola usaha dengan baik. Karena itu, program kerja yang dilaksanakan diawali dengan penanaman pengetahuan tentang kewirausahaan, bagaimana penyebaran atau distribusi produk yang akan dipasarkan, dan membangun mental kewirausahaan yang lebih kuat kepada masyarakat desa melewati bengkel kerja entrepreneurship dan copywriting. Tujuannya, 
berbagai kegiatan tersebut dapat meningkatkan semangat dan keterampilan kewirausahaan warga desa dan pada gilirannya turut meningkatkan nilai ekonomi Desa Margamekar. Bengkel kerja menekankan pada pemberian pengetahuan dan keterampilan kepada warga yang memiliki usaha mengenai entrepreneurship, strategi pemasaran dalam berwirausaha, indikator keberhasilan dalam berwirausaha, teknik dalam mempromosikan produk lewat media sosial, aspek penting yang harus diperhatikan dalam mempromosikan produk lewat media sosial, dan manfaat dari mempromosikan produk lewat media sosial. Pembekalan pengetahuan dan keterampilan ini penting dilakukan karena di era digital ini, keberadaan marketplace seperti Bukalapak, Shopee, Tokopedia, dsb. merupakan peluang besar bagi masyarakat khususnya yang memiliki UMKM untuk memasarkan produknya lebih luas lagi (Susanti, Gunawan, \& Sukaesih, 2019).

Kegiatan bengkel kerja dilaksanakan atas kerjasama antara tim PPM, tim KKN, dan komunitas UMKM Desa Margamekar. Sebelum kegiatan bengkel kerja dilakukan, sekitar seminggu sebelumnya, tim KKN telah melakukan kegiatan pemetaan sosial dan analisis SWOT terhadap potensi kewirausahaan di Desa Margamekar. Dari hasil analisis pemetaan sosial dan SWOT diketahui bahwa terdapat beberapa potensi yang mendapatkan prioritas untuk didampingi oleh tim, antara lain usaha makanan khas seperti keripik cireng, opak, dan ranginang. Sementara untuk sektor wisata, terdapat beberapa lokasi di sekitar desa yang memiliki pemandangan alam yang indah dan unik, antara lain curug dan area kemping (camp ground). Berdasarkan data survei pemetaan sosial dan SWOT, tim juga memperoleh gagasan untuk mengembangkan kewirausahaan dengan menerapkan strategi marketing baik secara daring maupun luring. Untuk metode luring, tim melakukan observasi terhadap beberapa titik strategis di sekitar Sumedang untuk mempromosikan berbagai produk UMKM dan destinasi wisata unggulan di Desa Margamekar. Titik-titik strategis tersebut antara lain hotel, restoran, dan biro perjalanan. Pemasaran dilakukan melalui penyebaran booklet berisi produk-produk unggulan UMKM dan foto-foto destinasi wisata di Desa Margamekar.

Dalam kegiatan pengelolaan kewirausahaan, tim PPM dan KKN melakukan pendampingan langsung kepada warga pemilik UMKM. Pendampingan berfokus pada strategi pemasaran menggunakan internet yang dilakukan dengan cara membuat akun marketplace seperti Tokopedia, Bukalapak, dan Shopee. Selain itu, peserta juga dibekali cara membuat akun Instagram sebagai media diseminasi informasi dan promosi produkproduk yang akan dipasarkan. Kendala yang dihadapi oleh para peserta adalah keterampilan membuat caption di marketplace dan di Instagram. Karena itu, dalam kegiatan bengkel kerja tim memberikan materi copywriting sebagai sarana di mana para peserta dalam mengetahui teknik dasar dalam membuat caption postingan di Instagram. Dengan keterampilan tersebut, para peserta lebih percaya diri dan terdorong untuk berkreativitas memasarkan produk-produknya di Internet.

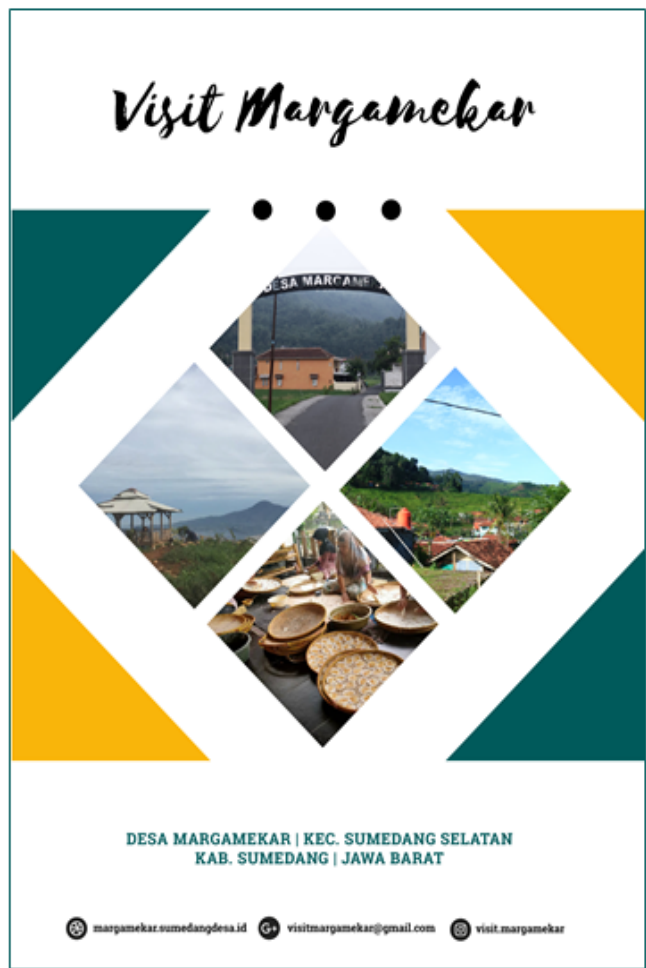

Gambar 1. Booklet produk UMKM dan Wisata Desa Margamekar

Sumber: Olahan tim PPM dan KKN Mahasiswa Tahun 2020

Proses ini memerlukan pendampingan lebih lanjut setelah bengkel kerja, karena para 
peserta belum terbiasa menggunakan Internet, terlebih lagi dalam pengelolaan akun-akun marketplace yang harus mengintegrasikan data, mulai dari alamat, ekspedisi, nomor rekening, dan nomor telepon. Namun, keberadaan tim KKN di desa sekitar satu bulan telah memberikan bimbingan secara intens kepada para warga pemilik UMKM dalam mengelola akun marketplace.

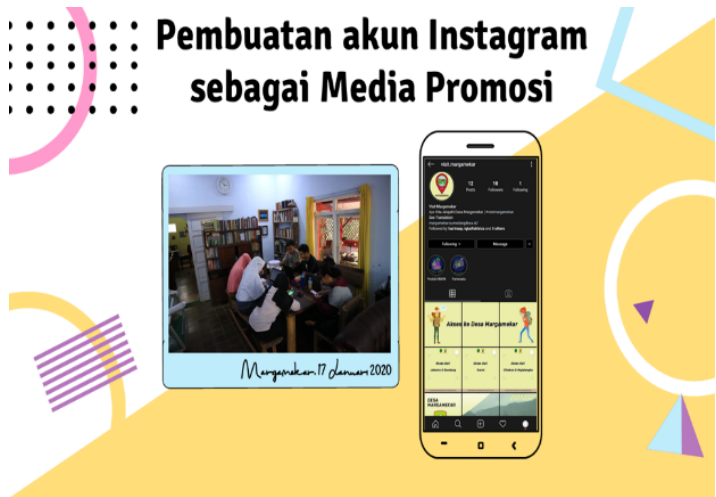

Gambar 2. Pembuatan akun Instagram untuk UMKM di Desa Margamekar

Sumber: Olahan tim PPM dan KKN

Mahasiswa tahun 2020

Salah satu indikator ketercapaiaan program bengkel kerja adalah adanya peningkatan pengetahuan yang terlihat melalui hasil pre-test dan post-test. Untuk menunjukkan hasil peningkatan tersebut, tim KKN mahasiswa melakukan uji beda agar dapat diketahui ada atau tidak adanya perbedaan yang signifikan antara hasil pre-test dan post-test peserta bengkel kerja. Dengan skala yang bersifat ordinal dan kelompok sampel yang sama antara kedua tesnya, digunakan uji Wilcoxon Signed-Rank Test menggunakan SPSS 24. Hasil yang diperoleh adalah sebagai berikut:

Tabel 1. Hasil Test Peningkatan Pengetahuan Peserta Bengkel Kerja

\section{Test Statistics ${ }^{a}$}

\begin{tabular}{|l|r|}
\hline & Post - Pre \\
\hline$Z$ & $-3.062^{\mathrm{b}}$ \\
Asymp. Sig. (2-tailed) & .002 \\
\hline
\end{tabular}

a. Wilcoxon Signed Ranks Test

b. Based on negative ranks.
Dengan alpha sebesar .05, dan diperoleh p-value sebesar .002, disimpulkan bahwa terdapat perbedaan yang signifikan positif antara hasil pre-test dan post-test. Hal tersebut menunjukkan adanya peningkatan pengetahuan yang disebabkan oleh pemberian materi di kegiatan bengkel kerja, sehingga kegiatan yang dilakukan tergolong berhasil. Sasaran dari acara bengkel kerja ini adalah seluruh warga Desa Margamekar khususnya pelaku UMKM di desa yang terealisasikan dengan kehadiran peserta seminar KKN KWU terdiri atas Aparatur Desa, Ketua RW dan RW serta pelaku UMKM.

\section{Lokakarya Penerapan Prinsip Penta helix}

Rangkaian kegiatan PPM dan KKN diakhiri dengan acara lokakarya yang bertema penerapan prinsip penta helix dalam pengembangan potensi kewirausahaan di Desa Margamekar. Acara ini ditujukan untuk meningkatkan kesadaran warga desa tentang pentingnya menjalin jejaring mitra kerja sama dengan berbagai pihak, terutama swasta, komunitas, pemerintah, perguruan tinggi, dan media massa. Warga desa yang memiliki usaha didorong untuk memiliki rasa percaya diri bahwa terdapat banyak pihak yang memiliki visi yang sama yakni membantu mendorong potensi UMKM di Desa Margamekar. Dalam acara ini terdapat beberapa materi yang disampaikan kepada para peserta, antara lain dari pihak Universitas Padjadjaran (dalam hal ini diwakili oleh dosen PPM) menyampaikan tentang pengertian penta helix dan kegunaan prinsip tersebut apabila diterapkan dalam mengelola potensi kewirausahaan di Desa Margamekar. Pada intinya, desa perlu memanfaatkan berbagai pihak dan lembaga baik yang ada di desa tersebut maupun yang ada di sekitarnya dalam rangka mencapai tujuantujuan yang terkait dengan pengembangan usaha. Desa perlu memperkuat peran BUMDes dalam pengelolaan potensi kewirausahaan dan para usahawan di desa bersama-sama memperkuat BUMDes dengan cara memberikan kontribusi atas segala pelayanan yang telah diberikan oleh BUMDes.

Dari pihak pemerintahan, kepala desa memberikan paparan tentang bagaimana 
pemerintah desa berperan dalam mendorong para pemilik UMKM di wilayah administrasinya. Selain menunjukkan berbagai potensi wisata yang terdapat di Margamekar, kepala desa juga menyampaikan visinya dalam membangun BUMDes sebagai portal dalam pengembangan UMKM. Senada dengan pemateri dari Universitas Padjadjaran, kepala desa juga menekankan sentralitas peran BUMDes yang pada saat itu belum lama dibentuk. Pemerintah desa menyambut baik kegiatan Universitas Padjadjaran yang dapat membantu konsep pengembangan yang tepat sasaran bagi BUMDes dalam meningkatkan kesejahteraan desa melalui pengelolaan potensi kewirausahaan dan pariwisata. Dari pihak media, tim PPM dan KKN mengundang jurnalis dari CNN Indonesia yang biasa meliput UMKM di sekitar Jawa Barat. Dalam paparannya, terungkap bahwa media memiliki peran penting dalam mendiseminasikan berita-berita tentang perkembangan UMKM. Bagi para pemilik UMKM, bekerja sama dengan media dapat dimanfaatkan sebagai media promosi gratis. Namun, masih banyak usahawan yang belum tahu kiat-kiat agar usaha mereka diliput oleh media. Jurnalis CNN Indonesia kemudian menjelaskan berbagai tips agara suatu usaha dapat diliput, antara lain jenis usaha harus menarik atau unik dan atau usaha tersebut menjadi sumber penghidupan bagi komunitas di suatu wilayah. Selain itu, pihak media juga memberikan pembekalan tentang aspek apa saja yang perlu dimiliki oleh pemilik UMKM agar produk atau jasanya dapat dikatakan memiliki keunikan.

Paparan terakhir yang diberikan pada acara lokakarya adalah tentang prosedur peminjaman modal di bank. Tim PPM dan KKN bekerja sama dengan Bank Jabar yang berkantor dekat dengan Desa Margamekar. Dalam kesempatan itu, pihak dari bank menjelaskan secara rinci produk-produk pinjaman modal yang tersedia khusus bagi UMKM. Kebanyakan dari produk tersebut merupakan bagian dari program pemerintah pusat dan Pemerintah Provinsi Jawa Barat dalam mendorong perekonomian melalui UMKM. Pinjaman modal untuk UMKM telah dirancang supaya memudahkan bagi warga desa dalam mengakses program tersebut. Misalnya, dengan jumlah yang relatif sedikit antara lima sampai 200 juta program pinjaman tidak mensyaratkan jaminan selayaknya pinjamanpinjaman konvensional. Bahkan terdapat program pinjaman bergilir yang jaminannya berupa modal sosial yakni jaminan dari komunitas masjid. Para peserta terlihat antusias dengan berbagai skema pinjaman ringan yang ditawarkan oleh Bank Jabar Banten. Dengan adanya sosialisasi pinjaman di bank, masyarakat diharapkan tidak lagi mengandalkan rentenir yang sering disebut 'bank tuyul' untuk mengakses modal. Sebab, selama ini keberadaan 'bank tuyul' telah memberikan dampak merusak pada tatanan masyarakat. Terdapat beberapa kejadian di mana si peminjam kesulitan membayar cicilan dan bunga yang besar dan akhirnya ia kabur dari rumah meninggalkan anak istrinya. Tidak sedikit pula para korban serupa yang mengalami stress. Karena itu, peran bank pemerintah perlu lebih proaktif di masyarakat agar warga tidak lagi mengalami masalah dengan 'bank tuyul.'

Secara keseluruhan, kegiatan lokakarya penerapan prinsip penta helix dalam pengelolaan kewirausahaan di Desa Margamekar berjalan sesuai dengan tujuan dan harapan yang telah direncanakan. Kegiatan ini telah memenuhi indikator pencapaian acara lokakarya penerapan prinsip penta helix dalam pengelolaan potensi kewirausahaan di Desa Margamekar yakni peserta yang hadir seminar minimal mencapai 50 orang dan pemahaman peserta setelah pematerian minimal mencapai 80 persen. Faktor yang memengaruhi lancarnya kegiatan tersebut adalah antusias dan respon yang sangat tinggi dari masyarakat. Materi tentang peminjaman modal pada bank dan pengenalan media untuk pemasaran produk, diharapkan masyarakat dapat mengaplikasikannya dalam kehidupan seharihari untuk mulai berwirausaha atapun mengembangkan usaha yang telah dimiliki. Pemasaran mengenai peminjaman mosal dan pemasaran telah diatasi dengan edukasi peminjaman modal kepada bank serta 
pembuatan website, Instagram dan juga booklet sebagai media promosi. Berdasarkan dari hasil survei melalui kuesioner dapat disimpulkan bahwa seminar yang seminar yang terlaksana berhasil meningkatkan pengetahuan peserta baik mengenai prinsip penta helix, berbagai media yang dapat digunakan untuk memasarkan produk, maupun alur peminjaman modal berwirausaha untuk pengembangan UMKM.

\section{SIMPULAN}

Sebagian besar penduduk Desa Margamekar masih dalam taraf ekonomi menengah dan di ambang kemiskinan. Para penduduk umumnya memiliki mata pencaharian sebagai petani dan pelaku UMKM yang belum memilki keterampilan mumpuni. Padahal potensi yang dimiliki desa di bidang wirausaha sangatlah besar serta memiliki potensi pariwisata di sekitar desa yang dapat dimanfaatkan untuk meningkatkan kesejahteraan warga dan juga menambah pendapatan desa. Permasalahan utama yang dimiliki oleh Desa Margamekar untuk berwirausaha yaitu dari segi pemasaran sehingga dalam mengatasi permasalahan yang ada dibuatlah booklet, website dan Instagram sebagai media daring agar lebih diketahui oleh masyarakat luas. Karena itu, tim telah melaksanakan lokakarya kewirausahaan, bengkel kerja copywriting, dan mengenai prosedur peminjaman modal kepada bank untuk mengembangkan potensi UMKM dan pariwisata yang telah tersedia.

$$
\text { Memberikan pendampingan }
$$

kewirausahaan terutama dengan memanfaatkan sarana media sosial merupakan langkah dasar untuk mengembangkan potensi kewirausahaan dan pariwisata yang telah dimiliki. Harapannya, unit-unit usaha yang sehat dan sentra pariwisata baru dapat memberikan lapangan pekerjaan dan meningkatkan taraf kesejateraan seluruh warga Desa Margamekar. Artikel ini menyarankan supaya kegiatan pendampingan kewirausahan terhadap warga desa dapat dilaksanakan secara berkelanjutan apakah oleh pihak perguruan tinggi atau instansi pemerintah yang bekerja sama dengan swasta dan kelompok masyarakat.
Pendampingan kewirausahaan desa yang dilakukan oleh pemerintah terlihat kurang intens. Karena itu, prinsip penta helix yang dijalankan secara berkelanjutan diharapkan dapat lebih efektif dalam pengembangan potensi usaha desa.

\section{UCAPAN TERIMA KASIH}

Penulis mengucapkan terima kasih kepada Universitas Padjadjaran yang telah mendanai kegiatan PPM ini dan tim KKN Mahasiswa Desa Margamekar tahun 2020 yang telah membantu pelaksanaan kegiatan PPM.

\section{DAFTAR PUSTAKA}

Awaluddin, M. $2015 . \quad$ Digital Entrepreneurshift. Jakarta: PT. Gramedia Pustaka Utama.

Direktorat Riset Pengabdian Kepada Masyarakat dan Inovasi Universitas Padjadjaran. 2019. Pedoman Hibah Internal Riset dan Pengabdian Pada Masyarakat. Jatinangor: DRPMI Unpad.

Handayani, E. 2020. Desa Regeneratif 4.0. Yogyakarta: Deepublish Publisher.

Karlina, N., Halim, H. A., Azizi, M. F., Athusholihah, A., \& Tarliyah, A. (2019). PEMBERDAYAAN KEWIRAUSAHAAN MASYARAKAT DESA CISEMPUR DAN PENDAMPINGAN KEWIRAUSAHAAN BERBASIS ECOMMERCE. Kumawula: Jurnal Pengabdian Kepada Masyarakat, 3(2), 262-269.

Pemerintah Desa Margamekar. 2019. Profil Desa Margamekar. Sumedang: Pemerintah Desa Margamekar.

Sekkesaeter, U. B. 2016. Microfinance as a Case Study of Social Entrepreneurship in Norway, Social Entrepreneurship and Social Enterprises: Nordic Perspective (Editor: Linda Lundgaard Andersen, Malin Gawell and Roger Spear). Londong \& New York: Routledge.

Sugiarti, Y., Sari, Y., \& Hadiyat, M. A. (2020). Peranan E-Commerce untuk 
Meningkatkan Daya Saing Usaha Mikro Kecil dan Menengah (UMKM) Sambal di Jawa Timur. Jurnal Kumawula: Jurnal Pengabdian Kepada Masyarakat, 3(2), 298-309.

https://doi.org/https://doi.org/10/24198/k umawula.v3i2.28181

Susanti, S., Gunawan, W., \& Sukaesih. (2019). Pengembangan Pemasaran Bordir dan Kelom Geulis Tasikmalaya Melalui Media Sosial. Jurnal Kumawula: Jurnal Pengabdian Kepada Masyarakat, 2(3), 248-261. https://doi.org/http://10.24198/kumawula. vli3.25256

Vavilina, N. D., \& Skalaban, I. A. 2015. Social Mapping as a Tool for Public Participation, Regional Research of Russia, Vol. 5, hal. 66-72. DOI: https://doi.org/10.1134/S207997051501 0116

Widianingsih, I., Setiawan, H., \& Chuddin, M. 2020. Penguatan Kapasitas Pengelolaan BUMDes Cipta Rahayu di Desa Panjalu Kecamatan Cilengkrang Kabupaten Bandung, Kumawula, Vol. 3, No. 2, Agustus 2020, hal. 225-238. DOI: https://doi.org/10.24198/kumawula.v3i2. 26909 